\title{
Clarification: Characterising JUUL-related posts on Instagram
}

Czaplicki L, Kostygina G, Kim Y, et al. Characterising JUUL-related posts on Instagram. Tob Control [Epub ahead of print 02 Jul 2019]. doi: 10.1136/tobaccocontrol-2018-054824.

This is a clarification to the article Characterising JUUL-related posts on Instagram.

The use of the term 'affiliate' throughout the article is defined by the authors as referring to 'commercial entities seeking to identify with or benefit from association with another commercial brand like JUUL'.

The second bullet point in the box entitled 'What this paper adds' at the end of the article is amended as follows: 'JUUL is a popular high-tech vaping device and there is concern that JUUL and the burgeoning category of JUUL-like e-cigarettes could addict a new generation of users'.

(C Author(s) (or their employer(s)) 2020. No commercial re-use. See rights and permissions. Published by BMJ.

Tob Control 2020;29:480. doi:10.1136/tobaccocontrol-2018-054824corr1

(D) Check for updates 